\title{
Matt Morgan: Meetings without meat
}

\author{
Matt Morgan intensive care consultant \\ University Hospital of Wales
}

The flowers in my garden sprouted before the Christmas tree was taken down. Australia welcomed the New Year alight with fire. The year has hardly begun, but the climate emergency is set to be the story of 2020 .

It's hard to raise a glass to the next decade while the climate emergency causes more deaths than smoking, AIDS, diabetes, and vehicle crashes combined, putting increased pressure on healthcare services. ${ }^{1}$ Climate related illness and injury disproportionately affect low income communities-another example of the poorest and most vulnerable people bearing the largest burden of ill health. And yet, while health providers are busy treating the effects of climate related illness, the healthcare sector's carbon dioxide output is equivalent to $4.4 \%$ of global greenhouse gas emissions. If healthcare were a country it would be the fifth largest polluter. ${ }^{2}$

Alarm is all very well, but what about solutions? As I fly home from another overseas conference it's embarrassing that my talk about respiratory disease was powered by jet fuel, while the calories provided by the conference were delivered through meat. The lights that brought my colourful slides of battered lungs to life took their energy from the coal that coated the insides of the patient I was trying to save.

Help me to start a movement at our medical conferences: I want organisers to commit to providing food that doesn't bloat the atmosphere as well as those eating it. A meat-free lunch would do little to dampen spirits but could hopefully be a start to dampening forest fires over the next decade. A quarter of global emissions come from food production-half of them from animal product emissions, chiefly beef and lamb. Livestock contributes to global warming not only through methane production but through deforestation linked to expanded pastures, and the Intergovernmental Panel on Climate Change is pleading for us to switch to a plant based diet.
If air travel is unavoidable in allowing human connections at conferences, we should nudge speakers to use honorariums or travel costs to cover ethical carbon offsetting projects, and this should be built into the travel expenses policy.

However, even not-for-profit companies providing ethical carbon offsetting are not the whole solution. Organisers could cover travel costs of only the most efficient airlines or advocate train travel for short haul alternatives. With online streaming and virtual connections, travelling halfway around the world to watch someone present slides and to check your emails at the back of a lecture theatre seems a little odd.

Finally, venues should be chosen not only for delegates' convenience but also to improve our lives now and those of future generations. Selecting facilities that commit to renewable energy is a price worth paying for organisers, delegates, and the planet.

Competing interests: I have read and understood BMJ policy on declaration of interests and declare that I have no competing interests.

Provenance and peer review: Commissioned; not externally peer reviewed.

Matt Morgan is an honorary senior research fellow at Cardiff University, consultant in intensive care medicine, research and development lead in critical care at University Hospital of Wales, and an editor of BMJ OnExamination.

1. Henderson C. Choked by Beth Gardiner review—-the toxic truth about the air we breathe. Guardian 2019 Apr 3. https://www.theguardian.com/books/2019/apr/03/choked-by-bethgardiner-review.

2 Healthcare Without Harm. Health care climate footprint report. Sep 2019. https://noharmglobal.org/sites/default/files/documents-files/5961/HealthCaresClimateFootprint_092319. pdf.

Published by the BMJ Publishing Group Limited. For permission to use (where not already granted under a licence) please go to http://group.bmj.com/group/rights-licensing/ permissions 